\title{
The Association between Soy Food and Breast Cancer; a Multicenter Cross-Sectional Study at Taif City, Saudi Arabia
}

\author{
Alnefaie S., M.D ${ }^{1}$, Alqashqari K. ${ }^{* 2}$, Almalki A. ${ }^{3}$, Baabbad A. ${ }^{4}$, Alrabie A. ${ }^{5}$, Almalki N. ${ }^{6}$ \\ ${ }^{1}$ Assistant Professor, College of Medicine, General Surgery Department, Taif University, Taif, Saudi Arabia; \\ drsahar22@gmail.com \\ ${ }^{2}$ Medical Intern, College of Medicine, Taif University, Taif, Saudi Arabia; Khairiah.yaqoub@gmail.com \\ ${ }^{3} 6^{\text {th }}$ Year Medical Student, College of Medicine, Taif University, Taif, Saudi Arabia; Amal8466@ gmail.com \\ ${ }^{4}$ Medical Intern, College of Medicine, Taif University, Taif, Saudi Arabia; ameera.as89@gmail.com \\ ${ }^{5}$ Medical Intern, College of Medicine, Taif University, Taif, Saudi Arabia; otbaiosh@ gmail.com \\ ${ }^{6}$ Medical Intern, College of Medicine, Taif University, Taif, Saudi Arabia; Nadeish.2015@gmail.com \\ *Corresponding Author: Khairiah Y Alqashqari; Khairiah.yaqoub@gmail.com
}

Received 12 November 2021;

Accepted 28 November 2021;

Published 01 December 2021

\begin{abstract}
Background: Breast cancer (BC) has a high incidence rate among females (3 to 8 per 1000) and is one of the most common causes of cancerrelated death. Diet is considered one of the risk factors in BC. Phytoestrogens are chemical components similar to estrogen in structure. An isoflavone is a major group of phytoestrogens, and it is found in food like soy products. Aim: Our study investigates the association between soy food intake, BC development and mammogram density among women in Taif City, Saudi Arabia. Methods: A descriptive cross-sectional study was conducted in three hospitals in Taif City, Saudi Arabia. The data was gathered using a questionnaire created by the authors. Phone interviews were conducted with female patients who visited breast/general surgery clinics from January to July 2020. Results: A total of 194 patients participated in this study. We observed that only two female patients (1.03\%) had a history of high soya intake, and both developed BC $(\mathrm{p}=0.011)$. One-third $(33.5 \%)$ showed scattered areas of fibro-glandular densities in a mammogram. Conclusion: We found that a large amount of soy food intake was significantly associated with a higher risk of BC. There is no relationship between mammogram density and age based on soya intake. More prospective studies with larger sample sizes in different cities of Saudi Arabia are needed to confirm this association.
\end{abstract}

Keywords: Soy Food, Phytoestrogens, Isoflavones, Mammogram Density, Breast Cancer.

\section{Introduction}

Breast cancer (BC) is considered the most common cancer diagnosed among women and is the leading cause of death from cancer ${ }^{[1]}$. The incidence of $\mathrm{BC}$ among Saudi female patients ranged between 3 to 8 confirmed $\mathrm{BC}$ cases per 1000 patients from 2010 to 2017, with the highest incidence rate in $2017^{[2]}$. Additionally, BC can affect men and is not limited to women ${ }^{[3]}$. Many risk factors can induce $\mathrm{BC}$, such as race, ethnicity, oral contraceptive use, age at first menstruation, menopausal age, age at first childbirth, and diet ${ }^{[4]}$.

Phytoestrogens are natural compounds chemically similar to estrogens and found mainly in plants such as soybeans, fruits, vegetables, and whole grains ${ }^{[5,6]}$. Furthermore, they have three main classes, among which are the isoflavones [7]. Isoflavones have three forms (genistein, daidzein, and glycitein) found in soy products, beans, peas, and nuts ${ }^{[7]}$. Food that contains soybean is widely consumed in Western countries (including flour, oil, milk, yogurt, cheese, sausages, and vegetarian burgers), containing many folds more isoflavones than Asian soy products ${ }^{[8]}$.

The chemical structure of genistein is very similar to the ovarian estrogen, estradiol (E2) ${ }^{[9]}$, as well as binding and activating both estrogen receptors $(E R \alpha \text { and } E R \beta)^{[10]}$. The function of $E R \alpha$ was to mediate the proliferative effects of estrogens, while $\mathrm{ER} \beta$ binds to $\mathrm{ER} \alpha$ and inhibits its effect ${ }^{[10,11]}$. Additionally, genistein binds more strongly to ER $\beta$ than to ER $\alpha^{[12]}$ and activates ER $\alpha$ equally as well as E2 ${ }^{[13]}$. The action of genistein on both ERs depends on the developmental stage of the breast: ER $\beta$ is expressed 
at a higher level than ER $\alpha$ during early development while in the breast tumor, ER $\alpha$ expression is more elevated than ER $\beta$ expression ${ }^{[14]}$. Soy products are considered a natural alternative to hormone replacement therapy (HRT) because these phytoestrogens do not involve any risk similar to HRT ${ }^{[15]}$.

The relationship between soy food and BC has remained confusing over the past years. A review article reported that several previous studies found that $\mathrm{BC}$ in Asian people was lower than other populations because they consume high levels of isoflavones as a part of their usual diet ${ }^{[4]}$. Many similar studies have shown that regular and high consumption of soy foods, including isoflavones, reduced the risk of $\mathrm{BC}{ }^{[16-18]}$. In contrast, others found that genistein stimulates the growth of existing estrogen-dependent tumors ${ }^{[19,20]}$.

A mammogram is considered an X-ray photograph of the breast and is known as a biomarker for BC. Several studies demonstrate the effect of soy intake on mammogram density inform of increased percent mammographic density (PMD) ${ }^{[21-23]}$. Furthermore, another research found that lower PMD was associated with high soy intake ${ }^{[23]}$. On the other hand, a review article showed no overall effect of isoflavones intake on PMD in postmenopausal women but might cause a small increase in breast density in premenopausal women ${ }^{[24]}$.

Nowadays, soy consumption is widespread among people in Saudi Arabia. During the previous 25 years, many studies worldwide have investigated the connection between soycontaining food and BC. However, there are insufficient studies on this subject in Saudi Arabia. This study, aimed to assess the association between soy consumption and $\mathrm{BC}$ and its effect on mammogram density among women in Taif City, Saudi Arabia.

\section{Method}

A random cross-sectional study was conducted in three hospitals in Taif City, Saudi Arabia, from July 2020 to October 2020. We obtained ethical approval from the Taif ethical committee.

The sample size was 973 patients. Of these, 336 did not answer the phone or their cell-phones were turned off, and 443 did not meet our inclusion criteria, so the sample size became 194 participants. Inclusion criteria: All female patients who visited breast/general surgery clinics from January to July 2020 and have a mammogram done during the past two years. The included hospitals are Alhada Armed Forces Hospital, King Abdulaziz Specialist Hospital and King Faisal Specialist Hospital, at Taif city, Saudi Arabia. Exclusion criteria: Male patients with BC.

The data was collected through a questionnaire designed by the authors except for the food assessment section. Phone interviews were conducted with the participants. The questionnaire included the demographic data (e.g., gender, age, nationality, and social status), risk factors of BC (previous history of BC or family history, HRT, radiation, oral contraceptive, age of menarche, menopause, and age of first pregnancy), and a yes/no question to assess the previous surgery or chemotherapy. For the food assessment section of the questionnaire, we used a validated semiquantitative food frequency questionnaire (FFQ) and the food items taken from American references ${ }^{[25]}$. However, we deleted food that is not sold in our country and added the nutrients that contain soy, available in Saudi Arabia. Mammogram density results were classified based on BIRAD Lexicon into four categories: A, the breasts are almost entirely fatty; B, there are scattered areas of fibro-glandular densities; C, the breasts are heterogeneously dense; and $\mathrm{D}$, the breasts are extremely dense.
The data collected were analyzed using SPSS version 23 (IBM Corp. Chicago, USA). The normality of the main continuous variable was tested for normality and found to be normally distributed (Shapiro-Wilk test, $\mathrm{p}>0.05$ ). Continuous variables were expressed using mean and standard deviations and categorical variables using frequencies and percentages. Pearson's Chi-square test was used to evaluate the statistical relationship between categorical variables. A multivariate analysis was run for some of the related variables to gain a greater understanding of correlations. A p-value of $\leq 0.05$ was considered statistically significant.

\section{Results}

A total of 194 patients participated in this study. The majority of the participants were Saudis, $97.4 \%(\mathrm{n}=189)$, and only $2.6 \%(\mathrm{n}=$ 5 ) were non-Saudis. The percentage of females who had breast cancer in our study was found to be $23.7 \%(\mathrm{n}=46)$. There was no significant association observed with socio-demographic characteristics of the participants except with education. Participants with no primary education showed a higher prevalence of breast cancer $(35 \%)$ than graduated $(20.3 \%)$, and high secondary school participants $(17.3 \%)(\mathrm{P}=0.043)$ [Table 1].

When we compared the reported prevalence of $\mathrm{BC}$ according to BMI, it was found that $20.8 \%$ of obese and $22.2 \%$ of overweight participants had BC, but there was no statistically significant association $(\mathrm{P}=0.684)$. In participants who did regular physical activities or exercise, $23.1 \%$ had BC, whereas this proportion was $24.7 \%$ in those who did not do regular physical activities or exercise $(\mathrm{P}=0.798)$. There was no significant difference seen in $\mathrm{BC}$ prevalence between tobacco smokers $(38.5 \%)$ and non-smokers $(22.7 \%)(\mathrm{P}=0.195)$. Female patients who reported a positive family history of $\mathrm{BC}$ showed a greater incidence of $\mathrm{BC}(34.5 \%)$ than those who did not have a family history (19.4\%), which showed a statistically significant association $(\mathrm{P}=0.026)$. In this study, $10.3 \%(\mathrm{n}=20)$ had reported a family history of ovarian cancer (OC). Among them, $40 \%(\mathrm{n}=8)$ had BC, whereas this proportion was $21.5 \%(\mathrm{n}=38)$ among those who did not have a family history of OC $(\mathrm{P}=0.071)$. The incidence of BC was $31.4 \%$ in females who had HRT and $22.5 \%$ in females who used hormonal contraceptives. Neither of these factors had a statistically significant association with BC. There was no statistical difference in the incidence of $\mathrm{BC}$ seen between females who had induced pregnancy $(20.7 \%)$ and had normal pregnancy $(24.2 \%) \quad(\mathrm{P}=0.678)$. There was no statistically significant association of incidence of $\mathrm{BC}$ observed with early menarche $(P=0.328)$ and late menopause $(P=0.914)$. The percentage of females who had first pregnancy at late age was $7.2 \%(\mathrm{n}=14)$, and the incidence of BC among these was found to be $21.4 \%$, whereas it was $23.9 \%$ in the female patients who had their first pregnancy at an earlier age $(\mathrm{P}=0.835)$ [Table 2].

Our study observed that only two females $(1.03 \%)$ had high soya intake, and both developed BC $(\mathrm{P}=0.011)$, which is a statistically significant difference [Table 3]. The mammogram findings showed that $13.9 \%$ showed extremely dense breast, $15.5 \%$ showed entirely fatty type, $33.5 \%$ showed scattered areas of fibroglandular densities, and $37.1 \%$ heterogeneously dense type [Figure 1]. When we ran a multivariate analysis to assess the relationship of mammogram findings with age based on soya intake, we found no statistically significant difference between the different age groups for soya intake $(\mathrm{P}>0.05)$ [Table 4]. The prevalence of BC was more remarkable in females who had high soya intake among patients aged 35-44 years old, but this did not reach statistical significance $(P=0.060)$ [Table 5] 
Table 1: Socio-demographic data and Breast cancer

\begin{tabular}{|c|c|c|c|c|c|c|}
\hline & & \multicolumn{2}{|c|}{ Breast cancer } & \multirow[t]{2}{*}{ Total } & \multirow[b]{2}{*}{$X^{2}$ value } & \multirow[t]{2}{*}{ P value } \\
\hline & & No & Yes & & & \\
\hline \multirow[t]{4}{*}{ Nationality } & \multirow[t]{2}{*}{ Saudi } & 144 & 45 & 189 & \multirow[t]{4}{*}{0.039} & \multirow[t]{4}{*}{0.843} \\
\hline & & $76.2 \%$ & $23.8 \%$ & $100.0 \%$ & & \\
\hline & \multirow[t]{2}{*}{ Non-Saudi } & 4 & 1 & 5 & & \\
\hline & & $80.0 \%$ & $20.0 \%$ & $100.0 \%$ & & \\
\hline \multirow[t]{8}{*}{ Social status } & \multirow[t]{2}{*}{ Single } & 7 & 3 & 10 & \multirow[t]{8}{*}{3.568} & \multirow[t]{8}{*}{0.312} \\
\hline & & $70.0 \%$ & $30.0 \%$ & $100.0 \%$ & & \\
\hline & \multirow[t]{2}{*}{ Married } & 127 & 35 & 162 & & \\
\hline & & $78.4 \%$ & $21.6 \%$ & $100.0 \%$ & & \\
\hline & \multirow[t]{2}{*}{ Divorced } & 8 & 3 & 11 & & \\
\hline & & $72.7 \%$ & $27.3 \%$ & $100.0 \%$ & & \\
\hline & \multirow[t]{2}{*}{ Widow } & 6 & 5 & 11 & & \\
\hline & & $54.5 \%$ & $45.5 \%$ & $100.0 \%$ & & \\
\hline \multirow[t]{6}{*}{ Education } & \multirow[t]{2}{*}{ Graduated/ Post-graduate } & 47 & 12 & 59 & \multirow[t]{6}{*}{6.248} & \multirow[t]{6}{*}{0.043} \\
\hline & & $79.7 \%$ & $20.3 \%$ & $100.0 \%$ & & \\
\hline & \multirow{2}{*}{$\begin{array}{l}\text { High secondary school or } \\
\text { less }\end{array}$} & 62 & 13 & 75 & & \\
\hline & & $82.7 \%$ & $17.3 \%$ & $100.0 \%$ & & \\
\hline & \multirow[t]{2}{*}{ No primary education } & 39 & 21 & 60 & & \\
\hline & & $65.0 \%$ & $35.0 \%$ & $100.0 \%$ & & \\
\hline \multirow[t]{8}{*}{ Age } & \multirow[t]{2}{*}{$<24$ years } & 3 & 1 & 4 & \multirow[t]{8}{*}{2.644} & \multirow[t]{8}{*}{0.450} \\
\hline & & $75.0 \%$ & $25.0 \%$ & $100.0 \%$ & & \\
\hline & \multirow[t]{2}{*}{$25-34$ years } & 51 & 10 & 61 & & \\
\hline & & $83.6 \%$ & $16.4 \%$ & $100.0 \%$ & & \\
\hline & \multirow[t]{2}{*}{$35-44$ years } & 86 & 32 & 118 & & \\
\hline & & $72.9 \%$ & $27.1 \%$ & $100.0 \%$ & & \\
\hline & \multirow[t]{2}{*}{$>45$ years } & 8 & 3 & 11 & & \\
\hline & & $72.7 \%$ & $27.3 \%$ & $100.0 \%$ & & \\
\hline
\end{tabular}

Table 2: Relationship between breast cancer and other risk factors

\begin{tabular}{|c|c|c|c|c|c|c|}
\hline & & \multicolumn{2}{|c|}{ Breast Cancer } & \multirow[t]{2}{*}{ Total } & \multirow[t]{2}{*}{$\mathrm{X}^{2}$ Value } & \multirow[t]{2}{*}{$P$ value } \\
\hline & & No & Yes & & & \\
\hline \multirow[t]{8}{*}{ Body Mass Index } & \multirow[t]{2}{*}{ Under-weight } & 5 & 2 & 7 & \multirow[t]{8}{*}{1.494} & \multirow[t]{8}{*}{0.684} \\
\hline & & $71.4 \%$ & $28.6 \%$ & $100.0 \%$ & & \\
\hline & \multirow[t]{2}{*}{ Normal } & 33 & 14 & 47 & & \\
\hline & & $70.2 \%$ & $29.8 \%$ & $100.0 \%$ & & \\
\hline & \multirow[t]{2}{*}{ Overweight } & 49 & 14 & 63 & & \\
\hline & & $77.8 \%$ & $22.2 \%$ & $100.0 \%$ & & \\
\hline & \multirow[t]{2}{*}{ Obese } & 61 & 16 & 77 & & \\
\hline & & $79.2 \%$ & $20.8 \%$ & $100.0 \%$ & & \\
\hline \multirow{4}{*}{$\begin{array}{l}\text { Regular } \\
\text { Exercise }\end{array}$} & \multirow[t]{2}{*}{ No } & 58 & 19 & 77 & \multirow[t]{4}{*}{0.066} & \multirow[t]{4}{*}{0.798} \\
\hline & & $75.3 \%$ & $24.7 \%$ & $100.0 \%$ & & \\
\hline & \multirow[t]{2}{*}{ Yes } & 90 & 27 & 117 & & \\
\hline & & $76.9 \%$ & $23.1 \%$ & $100.0 \%$ & & \\
\hline \multirow[t]{4}{*}{ Smoking } & \multirow[t]{2}{*}{ No } & 140 & 41 & 181 & \multirow[t]{4}{*}{1.676} & \multirow[t]{4}{*}{0.195} \\
\hline & & $77.3 \%$ & $22.7 \%$ & $100.0 \%$ & & \\
\hline & \multirow[t]{2}{*}{ Yes } & 8 & 5 & 13 & & \\
\hline & & $61.5 \%$ & $38.5 \%$ & $100.0 \%$ & & \\
\hline \multirow[t]{4}{*}{ Family History Breast Cancer } & \multirow[t]{2}{*}{ No } & 112 & 27 & 139 & \multirow[t]{4}{*}{4.981} & \multirow[t]{4}{*}{0.026} \\
\hline & & $80.6 \%$ & $19.4 \%$ & $100.0 \%$ & & \\
\hline & \multirow[t]{2}{*}{ Yes } & 36 & 19 & 55 & & \\
\hline & & $65.5 \%$ & $34.5 \%$ & $100.0 \%$ & & \\
\hline \multirow[t]{4}{*}{ Family History Ovarian Cancer } & \multirow[t]{2}{*}{ No } & 136 & 38 & 174 & \multirow[t]{4}{*}{3.271} & \multirow[t]{4}{*}{0.071} \\
\hline & & $78.2 \%$ & $21.8 \%$ & $100.0 \%$ & & \\
\hline & \multirow[t]{2}{*}{ Yes } & 12 & 8 & 20 & & \\
\hline & & $60.0 \%$ & $40.0 \%$ & $100.0 \%$ & & \\
\hline Hormonal Replacement Therapy & No & 124 & 35 & 159 & 1.406 & 0.236 \\
\hline & & $78.0 \%$ & $22.0 \%$ & $100.0 \%$ & & \\
\hline & Yes & 24 & 11 & 35 & & \\
\hline & & $68.6 \%$ & $31.4 \%$ & $100.0 \%$ & & \\
\hline
\end{tabular}


International Journal of Innovative Research in Medical Science (IJIRMS)

\begin{tabular}{|c|c|c|c|c|c|c|}
\hline \multirow[t]{4}{*}{ Hormonal Contraceptive } & \multirow[t]{2}{*}{ No } & 48 & 17 & 65 & \multirow[t]{4}{*}{0.322} & \multirow[t]{4}{*}{0.570} \\
\hline & & $73.8 \%$ & $26.2 \%$ & $100.0 \%$ & & \\
\hline & \multirow[t]{2}{*}{ Yes } & 100 & 29 & 129 & & \\
\hline & & $77.5 \%$ & $22.5 \%$ & $100.0 \%$ & & \\
\hline \multirow[t]{4}{*}{ Induced Pregnancy } & \multirow[t]{2}{*}{ No } & 125 & 40 & 165 & \multirow[t]{4}{*}{0.172} & \multirow[t]{4}{*}{0.678} \\
\hline & & $75.8 \%$ & $24.2 \%$ & $100.0 \%$ & & \\
\hline & \multirow[t]{2}{*}{ Yes } & 23 & 6 & 29 & & \\
\hline & & $79.3 \%$ & $20.7 \%$ & $100.0 \%$ & & \\
\hline \multirow[t]{4}{*}{ Early menarche } & \multirow[t]{2}{*}{ No } & 125 & 36 & 161 & \multirow[t]{4}{*}{0.955} & \multirow[t]{4}{*}{0.328} \\
\hline & & $77.6 \%$ & $22.4 \%$ & $100.0 \%$ & & \\
\hline & \multirow[t]{2}{*}{ Yes } & 23 & 10 & 33 & & \\
\hline & & $69.7 \%$ & $30.3 \%$ & $100.0 \%$ & & \\
\hline \multirow[t]{4}{*}{ Late menopause } & \multirow[t]{2}{*}{ No } & 141 & 44 & 185 & \multirow[t]{4}{*}{0.012} & \multirow[t]{4}{*}{0.914} \\
\hline & & $76.2 \%$ & $23.8 \%$ & $100.0 \%$ & & \\
\hline & \multirow[t]{2}{*}{ Yes } & 7 & 2 & 9 & & \\
\hline & & $77.8 \%$ & $22.2 \%$ & $100.0 \%$ & & \\
\hline \multirow[t]{4}{*}{ Late age of first pregnancy } & \multirow[t]{2}{*}{ No } & 137 & 43 & 180 & \multirow[t]{4}{*}{0.043} & \multirow[t]{4}{*}{0.835} \\
\hline & & $76.1 \%$ & $23.9 \%$ & $100.0 \%$ & & \\
\hline & \multirow[t]{2}{*}{ Yes } & 11 & 3 & 14 & & \\
\hline & & $78.6 \%$ & $21.4 \%$ & $100.0 \%$ & & \\
\hline
\end{tabular}

Table 3: Relationship of Soya intake and Breast cancer

\begin{tabular}{|c|c|c|c|c|c|c|}
\hline & & \multicolumn{2}{|c|}{ Breast Cancer } & \multirow[t]{2}{*}{ Total } & \multirow[t]{2}{*}{$\mathrm{X}^{2}$ Value } & \multirow[t]{2}{*}{$P$ value } \\
\hline & & No & Yes & & & \\
\hline \multirow[t]{4}{*}{ Soya intake/ per week } & \multirow[t]{2}{*}{ Low } & 148 & 44 & 192 & \multirow[t]{4}{*}{6.502} & \multirow[t]{4}{*}{$0.011 *$} \\
\hline & & $77.1 \%$ & $22.9 \%$ & $100.0 \%$ & & \\
\hline & \multirow[t]{2}{*}{ High } & 0 & 2 & 2 & & \\
\hline & & $0.0 \%$ & $100.0 \%$ & $100.0 \%$ & & \\
\hline
\end{tabular}

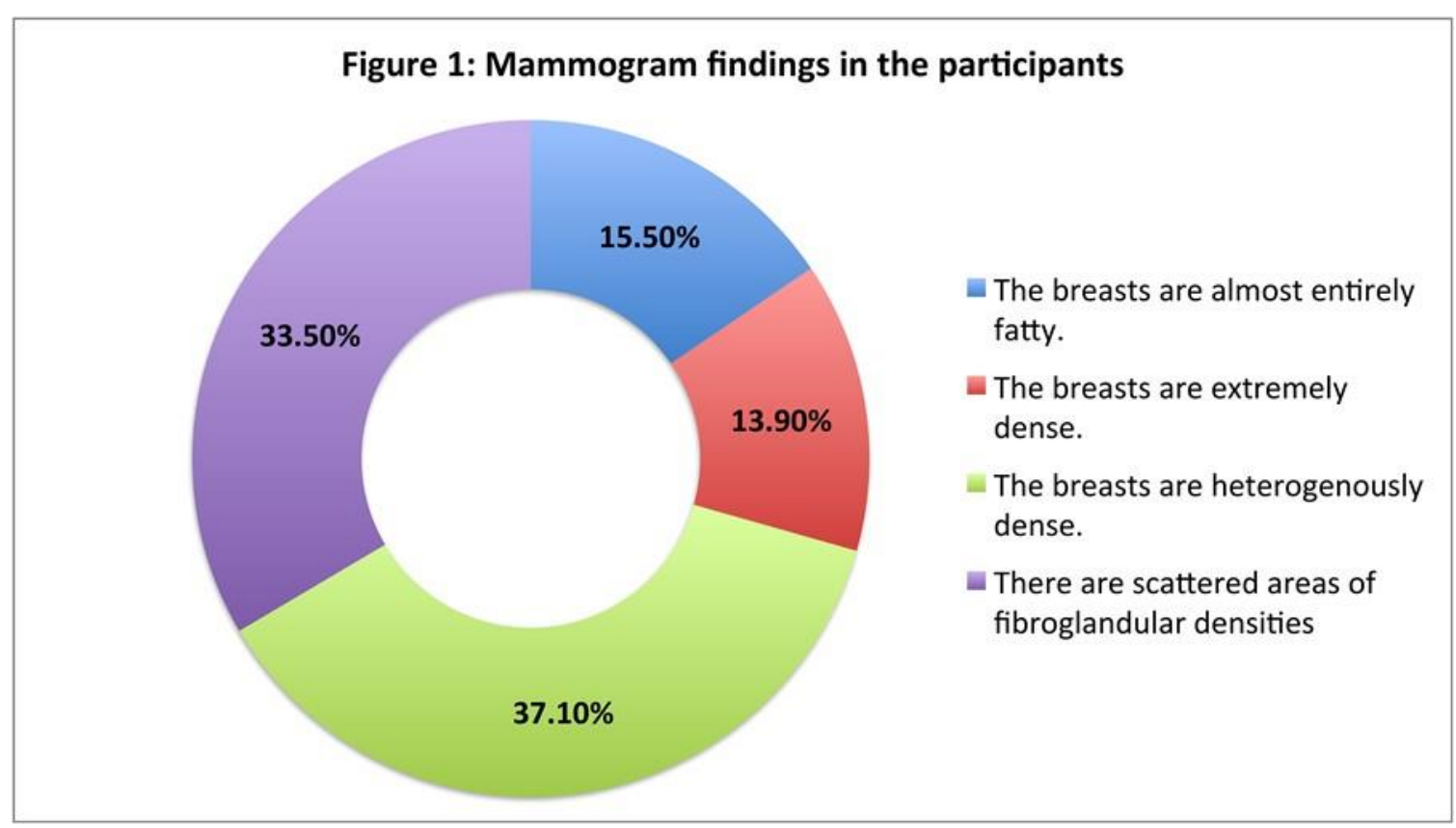

Table 4: A multivariate analysis of mammogram findings and age of the patients based on soya intake

\begin{tabular}{|c|c|c|c|c|c|c|c|c|}
\hline & \multirow[t]{2}{*}{ Soya intake } & & \multicolumn{4}{|l|}{ Age } & \multirow[t]{2}{*}{ Total } & \multirow{2}{*}{ P value } \\
\hline & & & $<25$ years & 25-34 years & 35-44 years & $>45$ years & & \\
\hline \multirow{4}{*}{$\begin{array}{l}\text { The breasts are almost entirely } \\
\text { fatty. }\end{array}$} & \multirow[t]{2}{*}{ Low } & $\mathrm{N}$ & 1 & 6 & 22 & 1 & 30 & \multirow[t]{4}{*}{ NA* } \\
\hline & & $\%$ & $3.3 \%$ & $20.0 \%$ & $73.3 \%$ & $3.3 \%$ & $100.0 \%$ & \\
\hline & \multirow[t]{2}{*}{ High } & $\mathrm{N}$ & 0 & 0 & 0 & 0 & 0 & \\
\hline & & $\%$ & $0.0 \%$ & $0.0 \%$ & $0.0 \%$ & $0.0 \%$ & $0.0 \%$ & \\
\hline \multirow[t]{4}{*}{ The breasts are extremely dense. } & \multirow[t]{2}{*}{ Low } & $\mathrm{N}$ & 1 & 13 & 12 & 1 & 27 & \multirow[t]{4}{*}{ NA* } \\
\hline & & $\%$ & $3.7 \%$ & $48.1 \%$ & $44.4 \%$ & $3.7 \%$ & $100.0 \%$ & \\
\hline & \multirow[t]{2}{*}{ High } & $\mathrm{N}$ & 0 & 0 & 0 & 0 & 0 & \\
\hline & & $\%$ & $0.0 \%$ & $0.0 \%$ & $0.0 \%$ & $0.0 \%$ & $0.0 \%$ & \\
\hline
\end{tabular}




\begin{tabular}{|c|c|c|c|c|c|c|c|c|}
\hline \multirow{4}{*}{$\begin{array}{l}\text { The breasts are heterogeneously } \\
\text { dense. }\end{array}$} & \multirow[t]{2}{*}{ Low } & $\mathrm{N}$ & 0 & 30 & 39 & 2 & 71 & \multirow[t]{4}{*}{0.667} \\
\hline & & $\%$ & $0.0 \%$ & $42.3 \%$ & $54.9 \%$ & $2.8 \%$ & $100.0 \%$ & \\
\hline & \multirow[t]{2}{*}{ High } & $\mathrm{N}$ & 0 & 0 & 1 & 0 & 1 & \\
\hline & & $\%$ & $0.0 \%$ & $0.0 \%$ & $100.0 \%$ & $0.0 \%$ & $100.0 \%$ & \\
\hline \multirow{4}{*}{$\begin{array}{l}\text { There are scattered areas of fibro- } \\
\text { glandular densities }\end{array}$} & \multirow[t]{2}{*}{ Low } & $\mathrm{N}$ & 2 & 12 & 43 & 7 & 64 & \multirow[t]{4}{*}{0.922} \\
\hline & & $\%$ & $3.1 \%$ & $18.8 \%$ & $67.2 \%$ & $10.9 \%$ & $100.0 \%$ & \\
\hline & \multirow[t]{2}{*}{ High } & $\mathrm{N}$ & 0 & 0 & 1 & 0 & 1 & \\
\hline & & $\%$ & $0.0 \%$ & $0.0 \%$ & $100.0 \%$ & $0.0 \%$ & $100.0 \%$ & \\
\hline
\end{tabular}

* NA: Not Applicable.

Table 5: A multivariate analysis of prevalence of breast cancer based on age and soya intake

\begin{tabular}{|c|c|c|c|c|c|c|}
\hline \multirow[t]{2}{*}{ Age } & \multirow[t]{2}{*}{ Soya intake } & & \multicolumn{2}{|c|}{ BREAST CANCER } & \multirow[t]{2}{*}{ Total } & \multirow[t]{2}{*}{ P value } \\
\hline & & & No & Yes & & \\
\hline \multirow[t]{4}{*}{$<25$ years } & \multirow[t]{2}{*}{ Low } & $\mathrm{n}$ & 3 & 1 & 4 & \multirow[t]{4}{*}{ NA* } \\
\hline & & $\%$ & $75.0 \%$ & $25.0 \%$ & $100.0 \%$ & \\
\hline & \multirow[t]{2}{*}{ High } & $\mathrm{n}$ & 0 & 0 & 0 & \\
\hline & & $\%$ & $0.0 \%$ & $0.0 \%$ & $0.0 \%$ & \\
\hline \multirow[t]{4}{*}{ 25-34 years } & \multirow[t]{2}{*}{ Low } & $\mathrm{n}$ & 51 & 10 & 61 & \multirow[t]{4}{*}{ NA* } \\
\hline & & $\%$ & $83.6 \%$ & $16.4 \%$ & $100.0 \%$ & \\
\hline & \multirow[t]{2}{*}{ High } & $\mathrm{n}$ & 0 & 0 & 0 & \\
\hline & & $\%$ & $0.0 \%$ & $0.0 \%$ & $0.0 \%$ & \\
\hline \multirow[t]{4}{*}{$35-44$ years } & \multirow[t]{2}{*}{ Low } & $\mathrm{n}$ & 75 & 41 & 116 & \multirow[t]{4}{*}{0.060} \\
\hline & & $\%$ & $64.7 \%$ & $35.3 \%$ & $100.0 \%$ & \\
\hline & \multirow[t]{2}{*}{ High } & $\mathrm{n}$ & 0 & 2 & 2 & \\
\hline & & $\%$ & $0.0 \%$ & $100.0 \%$ & $100.0 \%$ & \\
\hline \multirow[t]{4}{*}{$>45$ years } & \multirow[t]{2}{*}{ Low } & $\mathrm{n}$ & 10 & 1 & 11 & \multirow[t]{4}{*}{ NA* } \\
\hline & & $\%$ & $90.9 \%$ & $9.1 \%$ & $100.0 \%$ & \\
\hline & \multirow[t]{2}{*}{ High } & $\mathrm{n}$ & 0 & 0 & 0 & \\
\hline & & $\%$ & $0.0 \%$ & $0.0 \%$ & $0.0 \%$ & \\
\hline
\end{tabular}

*NA: Not Applicable.

\section{Discussion}

$\mathrm{BC}$ was diagnosed in over 2.3 million women, was responsible for 685,000 deaths worldwide in 2020 , and is considered the most prevalent cancer globally ${ }^{[26]}$. Our study found that there was a significant association between soy food and BC. This result is similar to previous studies that have reported that soy proteins were shown to stimulate existing estrogen-dependent tumors ${ }^{[27,28]}$. In contrast, various studies found no association between soy products and BC ${ }^{[29-31]}$. Explanation for these outcomes includes differences in ethnicity, age, amount of soy consumption, and other environmental factors among women.

Unlike the western region, the soy intake was low in all age groups in our study except in 35-44 year-olds, with two patients with high consumption. This could be due to dietary culture in our society, which depends mainly on non-soy products.

According to age group, BC prevalence was $25 \%$ among those less than 25 years old, $16.4 \%$ in $25-34$ years-year-olds, $27.1 \%$ in $35-44$ year-olds, and $27.3 \%$ in women older than 45 years old. This result is the opposite of a study done in 2019, which shows low-risk ER+ of BC in premenopausal and early menopausal women with soy supplements intake. This is consistent with the hypothesis that isoflavones' effects differ according to the estrogen milieu and have a weak estrogenic or anti-estrogenic action on low estrogen levels ${ }^{[31]}$.

Regarding the mammogram density (MD), the heterogeneously dense breast was the most common type in our participants, accounting for $37.1 \%$, then scattered area of fibroglandular densities $(33.5 \%)$, entirely fatty type (15.5\%), and extremely dense breast (13.9\%). This result is similar to a Chinese study ${ }^{[32]}$, which showed that about $50 \%$ of MD was heterogeneously dense, followed by scattered fibro-glandular densities (37\%), almost entirely fat (11\%), and extremely dense (3\%). Both studies applied to women with a high risk of BC. Our study found no significant difference between mammogram density and consumption of soy food, which is consistent with many studies ${ }^{[33-36]}$. On the other hand, a review article reported that soya intake in premenopausal women increases PMD ${ }^{[33]}$. Our research covered a small sample size and used BIRAD Lexicon to classify MD rather than PMD, which may explain this difference.

The current study findings show that $23.7 \%$ of the females had a history of $\mathrm{BC}$, which demonstrates that it is one of the most common malignancies in Saudi women, as reported in multiple studies in Saudi Arabia ${ }^{[37-39]}$. The current findings show that the prevalence is increasing dramatically. In 2018, Alotaibi et al. had reported that the prevalence of $\mathrm{BC}$ is $21.8 \%$, where $13.08 \%$ of the deaths among women were attributable to BC ${ }^{[40]}$. GLOBOCAN reported that approximately $34.2 \%$ of new cancer diagnoses in women were BC, and about $24.9 \%$ of deaths in the Middle East are related to this malignancy ${ }^{[41]}$. Our study findings did not show any difference in the prevalence of BC with marital status. However, it was reported that divorced, separated, or widowed women tend to lead an unhealthy lifestyle due to intense suffering in their personal and social life, which may increase the risk of $\mathrm{BC}^{[42]}$. A recent population-based study done by Zhai et al. had reported that married and single BC patients had a better prognosis than divorced, separated, or widowed patients ${ }^{[43]}$. Our study found that $\mathrm{BC}$ was significantly more common in women who had no primary education than in educated patients. Breast self-examination (BSE) is crucial for the early detection of $\mathrm{BC}$, and earlier studies indicate that education and socioeconomic status could influence the diagnosis and treatment of $\mathrm{BC}{ }^{[44,45]}$. Thus, it can be postulated that 
higher educational levels among women may positively affect BSE, which may help identify BC at its initial stages, leading to a better prognosis. Age is a risk factor for $\mathrm{BC}$ that is considered independent. A recent report showed that approximately $99.3 \%$ and $71.2 \%$ of all BC-associated deaths were in women over 40 and 60 years old, respectively ${ }^{[46]}$. Another recent study done in Saudi Arabia had reported that the average age for women who have been diagnosed with invasive BC is 51 years ${ }^{[47]}$. Thus, it is necessary to mammography screen all women after 40 years.

In addition, we reported that there was a clear association between high BMI and increased risk of BC in our participants. Similarly, a literature review found a greater risk for BC in women who gain weight in adulthood and overweight postmenopausal women than lean women ${ }^{[48]}$. We believe that obesity and metabolic syndrome are linked to the inflammatory environment that promotes $\mathrm{BC}$ tumor formation. Also, whole grains, vegetables and fruits, and fish lead to reduced inflammation, which reduces the risk of $\mathrm{BC}{ }^{[48]}$. We found that a quarter of women with $\mathrm{BC}$ had a positive family history of breast or ovarian cancer. A similar study in Iran reported that BC risk was significantly greater in women with a positive family history of $\mathrm{BC}{ }^{[49]}$. A positive family history of the disease is a substantial risk factor for $\mathrm{BC}$ at a young age. A young demographic structure and a combination of older age at menarche and younger age at first birth are both protective in later life ${ }^{[49]}$. Additionally, in our participants, there was no association between BC and other factors like smoking and HRT. A similar study found no statistically significant association between smoking and the risk of $\mathrm{BC}^{[50]}$.

\section{Conclusion}

Consumption of a large amount of soy is considered a risk factor for BC in this study, especially among the 35-44 age group. This result supports the importance of awareness of the impact of soy consumption on the etiology and prevention of $\mathrm{BC}$. There is no relationship between mammogram density and age based on soya intake. Further prospective studies to evaluate the exact amount and duration of soy intake are recommended to be conducted with a larger sample size in multiple cities in Saudi Arabia.

\section{Strength and limitation}

This research is one of a few studies carried out in Saudi Arabia to assess the association between soy food, BC risk and breast density. The small sample size limits our study. Also, no source in the Middle East shows the type of food containing soy protein (isoflavone) in our region, and different systems in the three included hospitals led to difficulty in collecting the mammogram density reports. However, we overcome this by using the BIRAD Scoring System. More studies are needed to evaluate a larger sample size, including the exact quantities and duration of soy food consumption. We recommend dietitians study and publish lists of food that contains soy that is available in Saudi Arabia and nearby.

\author{
Abbreviations \\ BC: Breast Cancer \\ HRT: Hormone Replacement Therapy \\ PMD: Percent Mammographic Density \\ FFQ: Food Frequency Questionnaire \\ MD: Mammogram Density \\ BSE: Breast Self-Examination
}

\section{Conflict of interest}

The authors declare that they have no competing interests.

\section{Funding}

Not applicable

\section{Acknowledgments}

The authors would like to thank Khaled Abdulrahman Almalki, a medical intern at Taif University, for his help in the data collection of this study. Also, we appreciate the assistance of Dr. Ibrahim Abdulaziz Alghamdi, Dr. Dalia El-Sayed Desouky Abdellah, and Dr. Najwa Eltayeb Ibrahim.

\section{References}

[1] Sung H, Ferlay J, Siegel RL, Laversanne M, Soerjomataram I, Jemal A, et al. Global cancer statistics 2020: GLOBOCAN estimates of incidence and mortality worldwide for 36 cancers in 185 countries. CA Cancer J Clin [Internet]. 2021 Feb 4 [cited 2021 May 12];71(3):209-49. Available from: https://acsjournals.onlinelibrary.wiley.com/doi/full/10.33 22/caac. 21660

[2] Asiri S, Asiri A, Ulahannan S, Alanazi M, Humran A, Hummadi A. Incidence Rates of Breast Cancer by Age and Tumor Characteristics Among Saudi Women: Recent Trends. Cureus [Internet]. 2020 Jan 15 [cited 2021 May 4];12(1). Available from: /pmc/articles/PMC6961791/

[3] Grundy A, Harris SA, Demers PA, Johnson KC, Agnew DA, Villeneuve PJ, et al. Occupational exposure to magnetic fields and breast cancer among Canadian men. Cancer Med [Internet]. 2016 Mar 1 [cited 2021 May 4];5(3):586-96. Available from: /pmc/articles/PMC4799956/

[4] Ziaei S, Halaby R. Dietary Isoflavones and Breast Cancer Risk. Medicines [Internet]. 2017 Apr 7 [cited 2021 May 4];4(4):18. Available from: https://pubmed.ncbi.nlm.nih.gov/28930233/

[5] Viggiani MT, Polimeno L, Di Leo A, Barone M. Phytoestrogens: Dietary intake, bioavailability, and protective mechanisms against colorectal neoproliferative lesions. Nutrients [Internet]. 2019 [cited 2021 May 6];11(8). Available from: /pmc/articles/PMC6722977/

[6] Kolátorová L, Lapčík O, Stárka L. Phytoestrogens and the Intestinal Microbiome. [cited 2021 May 6]; Available from: www.biomed.cas.cz/physiolresPhysiol.Res.67

[7] Jaworski M, Fabisiak A. The Bioavailability of Nutrients That Have a Health-Promoting Effect on Nervous System Function. In: Food Quality: Balancing Health and Disease. Elsevier Inc.; 2018. p. 225-52.

[8] Erdman JW, Badger TM, Lampe JW, Setchell KDR, Messina M. Not All Soy Products Are Created Equal: Caution Needed in Interpretation of Research Results. In: Journal of Nutrition [Internet]. American Institute of Nutrition; 2004 [cited 2021 May 4]. Available from: https://pubmed.ncbi.nlm.nih.gov/15113977/

[9] Su BYW, Tung TH, Chien WH. Effects of phytoestrogens on depressive symptoms in climacteric 
women: A meta-analysis of randomized controlled trials [Internet]. Vol. 24, Journal of Alternative and Complementary Medicine. Mary Ann Liebert Inc.; 2018 [cited 2021 May 4]. p. 850-1. Available from: https://pubmed.ncbi.nlm.nih.gov/29717895/

[10] Paech K, Webb P, Kuiper GGJM, Nilsson S, Gustafsson JÅ, Kushner PJ, et al. Differential ligand activation of estrogen receptors $\mathrm{ER} \alpha$ and $\operatorname{ERr} \beta$ at AP1 sites. Science (80) [Internet]. 1997 Sep 5 [cited 2021 May 4];277(5331):1508-10. Available from: https://pubmed.ncbi.nlm.nih.gov/9278514/

[11] Rajah TT, Du N, Drews N, Cohn R. Genistein in the presence of $17 \beta$-estradiol inhibits proliferation of ER $\beta$ breast cancer cells. Pharmacology [Internet]. 2009 Aug [cited 2021 May 4];84(2):68-73. Available from: https://pubmed.ncbi.nlm.nih.gov/19556829/

[12] Kuiper GGJM, Lemmen JG, Carlsson B, Corton JC, Safe $\mathrm{SH}$, Van Der Saag PT, et al. Interaction of estrogenic chemicals and phytoestrogens with estrogen receptor $\beta$. Endocrinology [Internet]. 1998 [cited 2021 May 4];139(10):4252-63. Available from: https://pubmed.ncbi.nlm.nih.gov/9751507/

[13] Chang EC, Charn TH, Park SH, Helferich WG, Komm B, Katzenellenbogen JA, et al. Estrogen receptors $\alpha$ and $\beta$ as determinants of gene expression: Influence of ligand, dose, and chromatin binding. Mol Endocrinol [Internet]. 2008 May [cited 2021 May 4];22(5):1032-43. Available from: https://pubmed.ncbi.nlm.nih.gov/18258689/

[14] Speirs V, Walker RA. New perspectives into the biological and clinical relevance of oestrogen receptors in the human breast [Internet]. Vol. 211, Journal of Pathology. J Pathol; 2007 [cited 2021 May 4]. p. 499506. Available from: https://pubmed.ncbi.nlm.nih.gov/17236182/

[15] Allred CD, Allred KF, Ju YH, Virant SM, Helferich WG. Soy Diets Containing Varying Amounts of Genistein Stimulate Growth of Estrogen-dependent (MCF-7) Tumors in a Dose-dependent Manner 1. Vol. 61, CANCER RESEARCH. 2001.

[16] Yamamoto S, Sobue T, Kobayashi M, Sasaki S, Tsugane $\mathrm{S}$, Tsugane $\mathrm{S}$, et al. Soy, isoflavones, and breast cancer risk in Japan. J Natl Cancer Inst [Internet]. 2003 Jun 18 [cited 2021 May 4];95(12):906-13. Available from: https://pubmed.ncbi.nlm.nih.gov/12813174/

[17] Zhu YY, Zhou L, Jiao SC, Xu LZ. Relationship between soy food intake and breast cancer in China. Asian Pacific J Cancer Prev. 2011;12(11):2837-40.

[18] Zhang C, Ho SC, Lin F, Cheng S, Fu J, Chen Y. Soy product and isoflavone intake and breast cancer risk defined by hormone receptor status. Cancer Sci. 2010 Feb;101(2):501-7.

[19] Hsieh CY, Santell RC, Haslam SZ, Helferich WG. Estrogenic effects of genistein on the growth of estrogen receptor- positive human breast cancer (MCF-7) cells in vitro and in vivo. Cancer Res. 1998;58(17):3833-8.

[20] Allred CD, Ju YH, Allred KF, Chang J, Helferich WG. Dietary genistin stimulates growth of estrogen-dependent breast cancer tumors similar to that observed with genistein. Carcinogenesis [Internet]. 2001 [cited 2021 May 4];22(10):1667-73. Available from: https://pubmed.ncbi.nlm.nih.gov/11577007/
[21] Maskarinec G, Meng L. An investigation of soy intake and mammographic characteristics in Hawaii. Breast Cancer Res [Internet]. 2001 [cited 2021 May 4];3(2):134-41. Available from: /pmc/articles/PMC13924/

[22] Jakes RW, Duffy SW, Ng F-C, Gao F, Ng E-H, Seow A, et al. Mammographic Parenchymal Patterns and Selfreported Soy Intake in Singapore Chinese Women 1. 2002.

[23] Ursin G, Sun CL, Koh WP, Khoo KS, Gao F, Wu AH, et al. Associations between soy, diet, reproductive factors, and mammographic density in Singapore Chinese Women. Nutr Cancer [Internet]. 2006 [cited 2021 May 4];56(2):128-35. Available from: https://pubmed.ncbi.nlm.nih.gov/17474857/

[24] Hooper L, Madhavan G, Tice JA, Leinster SJ, Cassidy A. Effects of isoflavones on breast density in pre-and postmenopausal women: A systematic review and metaanalysis of randomized controlled trials. Hum Reprod Update [Internet]. 2010 May 28 [cited 2021 May 4];16(6):745-60. Available from: https://pubmed.ncbi.nlm.nih.gov/20511398/

[25] Bhagwat S, Haytowitz DB, Holden JM. USDA Database for the Isoflavone Content of Selected Foods. 2008;

[26] Breast cancer [Internet]. [cited 2021 May 10]. Available from: https://www.who.int/news-room/factsheets/detail/breast-cancer

[27] Hsieh C-Y, Santell RC, Haslam SZ, Helferich WG. Estrogenic Effects of Genistein on the Growth of Estrogen Receptor-positive Human Breast Cancer (MCF7) Cells in Vitro and in Vivo. Cancer Res. 1998;58(17).

[28] Ju YH, Allred CD, Allred KF, Karko KL, Doerge DR, Helferich WG. Physiological concentrations of dietary genistein dose-dependently stimulate growth of estrogendependent human breast cancer (MCF-7) tumors implanted in athymic nude mice. J Nutr [Internet]. 2001 [cited 2021 May 9];131(11):2957-62. Available from: https://pubmed.ncbi.nlm.nih.gov/11694625/

[29] Fraser GE, Jaceldo-Siegl K, Orlich M, Mashchak A, Sirirat R, Knutsen S. Dairy, soy, and risk of breast cancer: Those confounded milks. Int $\mathrm{J}$ Epidemiol [Internet]. 2020 Oct 1 [cited 2021 May 9];49(5):1526$37 . \quad$ Available from: https://pubmed.ncbi.nlm.nih.gov/32095830/

[30] Shirabe R, Saito E, Sawada N, Ishihara J, Takachi R, Abe SK, et al. Fermented and nonfermented soy foods and the risk of breast cancer in a Japanese populationbased cohort study. Cancer Med [Internet]. 2021 Jan 1 [cited 2021 May 9];10(2):757-71. Available from: https://pubmed.ncbi.nlm.nih.gov/33340281/

[31] Touillaud M, Gelot A, Mesrine S, Bennetau-Pelissero C, Clavel-Chapelon F, Arveux P, et al. Use of dietary supplements containing soy isoflavones and breast cancer risk among women aged $>50$ y: A prospective study. Am J Clin Nutr [Internet]. 2019 Mar 1 [cited 2021 May 9];109(3):606-14. Available from: https://pubmed.ncbi.nlm.nih.gov/30831601/

[32] Sung H, Ren J, Li J, Pfeiffer RM, Wang Y, Guida JL, et al. Breast cancer risk factors and mammographic density among high-risk women in urban China. npj Breast Cancer [Internet]. 2018 Dec 1 [cited 2021 May 7];4(1):3. Available from: www.nature.com/npjbcancer 
[33] Hooper L, Madhavan G, Tice JA, Leinster SJ, Cassidy A. Effects of isoflavones on breast density in pre-and postmenopausal women: A systematic review and metaanalysis of randomized controlled trials. Hum Reprod Update [Internet]. 2010 May 28 [cited 2021 May 7];16(6):745-60. Available from: /pmc/articles/PMC2953939/

[34] Messina M, McCaskill-Stevens W, Lampe JW. Addressing the soy and breast cancer relationship: Review, commentary, and workshop proceedings [Internet]. Vol. 98, Journal of the National Cancer Institute. J Natl Cancer Inst; 2006 [cited 2021 May 7]. p. 1275-84. Available from: https://pubmed.ncbi.nlm.nih.gov/16985246/

[35] Powles TJ, Howell A, Evans DG, McCloskey E V., Ashley S, Greenhalgh R, et al. Red clover isoflavones are safe and well tolerated in women with a family history of breast cancer. Menopause Int [Internet]. 2008 Mar [cited 2021 May 7];14(1):6-12. Available from: https://pubmed.ncbi.nlm.nih.gov/18380954/

[36] Maskarinec G, Takata Y, Franke AA, Williams AE, Murphy SP. A 2-year soy intervention in premenopausal women not change mammographic densities. J Nutr [Internet]. 2004 [cited 2021 May 7];134(11):3089-94. Available

from: https://pubmed.ncbi.nlm.nih.gov/15514280/

[37] (PDF) Cancer Incidence Report Saudi Arabia 2002 [Internet]. [cited 2021 May 9]. Available from: https://www.researchgate.net/publication/296618914_Ca ncer_Incidence_Report_Saudi_Arabia_2002

[38] Mokdad AH, Jaber S, Abdel Aziz MI, Al Buhairan F, Al Ghaithi A, Al Hamad NM, et al. The state of health in the Arab world, 1990-2010: An analysis of the burden of diseases, injuries, and risk factors. Lancet [Internet]. 2014 [cited 2021 May 9];383(9914):309-20. Available from: https://pubmed.ncbi.nlm.nih.gov/24452042/

[39] Lozano R, Naghavi M, Foreman K, Lim S, Shibuya K, Aboyans V, et al. Global and regional mortality from 235 causes of death for 20 age groups in 1990 and 2010: A systematic analysis for the Global Burden of Disease Study 2010. Lancet [Internet]. 2012 Dec 1 [cited 2021 May 9];380(9859):2095-128. Available from: https://pubmed.ncbi.nlm.nih.gov/23245604/

[40] Alotaibi RM, Rezk HR, Juliana CI, Guure C. Breast cancer mortality in Saudi Arabia: Modelling observed and unobserved factors. PLoS One [Internet]. 2018 Oct 1 [cited 2021 May 9];13(10). Available from: https://pubmed.ncbi.nlm.nih.gov/30347002/

[41] Bray F, Ferlay J, Soerjomataram I, Siegel RL, Torre LA, Jemal A. Global cancer statistics 2018: GLOBOCAN estimates of incidence and mortality worldwide for 36 cancers in 185 countries. CA Cancer J Clin [Internet]. 2018 Nov [cited 2021 May 9];68(6):394-424. Available from: https://pubmed.ncbi.nlm.nih.gov/30207593/

[42] Li M, Han M, Chen Z, Tang Y, Ma J, Zhang Z, et al. Does marital status correlate with the female breast cancer risk? A systematic review and meta-analysis of observational studies. PLoS One [Internet]. 2020 [cited 2021 May 9];15(3). Available from: https://pubmed.ncbi.nlm.nih.gov/32134997/

[43] Zhai Z, Zhang F, Zheng Y, Zhou L, Tian T, Lin S, et al. Effects of marital status on breast cancer survival by age, race, and hormone receptor status: A population-based Study. Cancer Med [Internet]. 2019 Aug 1 [cited 2021 May 9];8(10):4906-17. Available from: https://pubmed.ncbi.nlm.nih.gov/31267686/

[44] Macleod U, Ross S, Gillis C, McConnachie A, Twelves C, Watt GCM. Socio-economic deprivation and stage of disease at presentation in women with breast cancer. Ann Oncol [Internet]. 2000 [cited 2021 May 9];11(1):105-7. Available from: https://pubmed.ncbi.nlm.nih.gov/10690397/

[45] Wang Q, Li J, Zheng S, Li JY, Pang Y, Huang R, et al. Breast cancer stage at diagnosis and area-based socioeconomic status: A multicenter 10-year retrospective clinical epidemiological study in China. BMC Cancer [Internet]. 2012 Mar 29 [cited 2021 May 9];12. Available from: https://pubmed.ncbi.nlm.nih.gov/22455370/

[46] Siegel RL, Miller KD, Jemal A. Cancer statistics, 2017. CA Cancer J Clin [Internet]. 2017 Jan [cited 2021 May 9];67(1):7-30. Available from: https://pubmed.ncbi.nlm.nih.gov/28055103/

[47] Asiri S, Asiri A, Ulahannan S, Alanazi M, Humran A, Hummadi A. Incidence Rates of Breast Cancer by Age and Tumor Characteristics Among Saudi Women: Recent Trends. Cureus [Internet]. 2020 Jan 15 [cited 2021 May 9];12(1). Available from: https://pubmed.ncbi.nlm.nih.gov/31966952/

[48] Braakhuis AJ, Campion P, Bishop KS. Reducing breast cancer recurrence: The role of dietary polyphenolics [Internet]. Vol. 8, Nutrients. MDPI AG; 2016 [cited 2021 May 9]. Available from: https://pubmed.ncbi.nlm.nih.gov/27608040/

[49] Ebrahimi M, Vahdaninia M, Montazeri A. Risk factors for breast cancer in Iran: A case-control study. Breast Cancer Res [Internet]. 2002 Oct 1 [cited 2021 May 9];4(5). Available from: https://pubmed.ncbi.nlm.nih.gov/12223127/

[50] Baset Z, Abdul-Ghafar J, Parpio YN, Haidary AM. Risk factors of breast cancer among patients in a tertiary care hospitals in Afghanistan: a case control study. BMC Cancer [Internet]. 2021 Dec 1 [cited 2021 May 18];21(1). Available from: https://pubmed.ncbi.nlm.nih.gov/33446123/

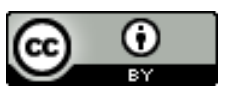

Open Access This article is licensed under a Creative Commons Attribution 4.0 International License, which permits use, sharing, adaptation, distribution and reproduction in any medium or format, as long as you give appropriate credit to the original author(s) and the source, provide a link to the Creative Commons license, and indicate if changes were made. The images or other third party material in this article are included in the article's Creative Commons license, unless indicated otherwise in a credit line to the material. If material is not included in the article's Creative Commons license and your intended use is not permitted by statutory regulation or exceeds the permitted use, you will need to obtain permission directly from the copyright holder. To view a copy of this license, visit https://creativecommons.org/licenses/by/4.0/.

(C) The Author(s) 2021 